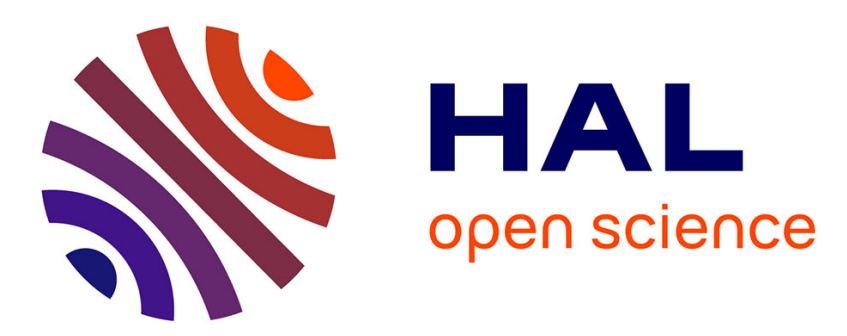

\title{
An ounce of prevention is worth a pound of cure: Fang homegarden organization as a means to prevent health risks
}

Edmond Dounias

\section{- To cite this version:}

Edmond Dounias. An ounce of prevention is worth a pound of cure: Fang homegarden organization as a means to prevent health risks. The Open Complementary Medicine Journal, 2010, The Open Complementary Medicine Journal, 2, pp.31-41. 10.2174/1876391X01002010031 . hal-03123950

\section{HAL Id: hal-03123950 \\ https://hal.science/hal-03123950}

Submitted on 15 Dec 2021

HAL is a multi-disciplinary open access archive for the deposit and dissemination of scientific research documents, whether they are published or not. The documents may come from teaching and research institutions in France or abroad, or from public or private research centers.
L'archive ouverte pluridisciplinaire HAL, est destinée au dépôt et à la diffusion de documents scientifiques de niveau recherche, publiés ou non, émanant des établissements d'enseignement et de recherche français ou étrangers, des laboratoires publics ou privés.

\section{(ㄷ)(1) $\$$}

Distributed under a Creative Commons Attribution - NonCommerciall 4.0 International 


\title{
An Ounce of Prevention is Worth a Pound of Cure. Fang Homegarden Organization as Means to Prevent from Health Risks
}

\author{
Edmond Dounias ${ }^{*}$
}

IRD, UMR 5175 CEFE, Campus CNRS, 1919 route de Mende, 34293 Montpellier Cedex 5, France

\begin{abstract}
The ethnobiological analysis of Fang homegardens in Southern Cameroon reveals striking contrasts between the frontyard and the backyard. Plants and their uses, as well as attitudes of villagers, clearly reflect opposite functions. The frontyard is a public space that is regularly maintained in a clean state. This is a pleasing and freely accessible space, where plants are mainly ornamental or provide only slight shade, as this space must remain well illuminated and offer a bright view. By contrast, the backyard is a dark private space. Access is restricted and protected by magic. In this space, people communicate with the supernatural world, discretely experiment with new magical, medicinal, and food plants. Like the two sides of a coin, the frontyard and the backyard have complementary values that can be understood only in the light of the turbulent history of the Fang. They constitute powerful physical, spatial and cultural poles that fulfill a series of embedded functions that mark out the life history of the Fang, the social relationships within different members of the communities, and the symbolically rich settings for everyday life and rituals. Ultimately, they form an assemblage that efficiently reduces exposure to diseases. The cultural control of risks on health does not only concern the physical and functional layouts of the landscape - that efficiently reduce the incidence of vector-borne and transmissible diseases - but it also concerns the symbolic control of supernatural forces, which are much less immediately tangible causes of sickness, pain, trouble, conflict and even death.
\end{abstract}

Keywords: Central Africa, homegarden, frontyard, courtyard, spatial organization, health risk avoidance.

\section{INTRODUCTION}

Homegardens are ubiquitous components of family farming systems around the world. For long dismissed, when not simply ignored, as a trivial sideline to the field system, the homegardens that are grown adjacent to houses throughout the tropics only recently deserved the attention of the scientific community. Since the pioneering work of Terra in 1954 [1], however, there has been an abundance of articles that have aimed to fill the deficit of knowledge concerning these pervasive components of the domestic space, which contribute to the livelihoods of millions of peoples in every latitude, economic context and culture [2-4]. Because they are located close by or directly adjacent to dwelling houses, homegardens tend to be part of the domestic rather than productive sphere. Their resources are primarily intended to address family self-sufficiency and sustainability needs rather than being for sale. Accordingly, they have taken the back seat to studies devoted to the agricultural systems. They are 'invisible' to the broader economy, and are often undervalued from that respect by their owners themselves.

A great majority of homegarden case studies are located in the Middle East, South-East Asia [5-9], the Caribbean [10] or Latin America [11-15] whereas the African continent - particularly the forested lands of Congo Basinremains largely unstudied [16-21]. The literature now abounds in describing their agricultural [22-25] ecological [26-28], and economical functions [29-31]. Much less

*Address correspondence to this author at the IRD, UMR 5175 CEFE, Campus CNRS, 1919 route de Mende, 34293 Montpellier cedex 5, France; Tel: (+33) 467613234; Fax: (+33) 467412138;

E-mail: edmond.dounias@ird.fr explored throughout the tropics are the social, cultural, aesthetic and symbolic values of homegardens [10,32,33], values which have long been documented in temperate latitudes by historians and anthropologists [34-39]. In fact, most data concerning tropical homegardens have been carried out by natural scientists. In one of the most recent books devoted to tropical homegardens, the editors persist in defining them as "microenvironments within a larger farming system that contain high levels of species or varieties of species different from those found in surrounding agroecosystems" [40]. Such a definition clearly propagates the prominent utilitarian and pragmatic perspectives that still prevail among studies on homegardens.

Until the late 1980 s, very few studies have explored the ethnomedicinal values of homegardens. Nevertheless, the recent growing interest on the contribution of homegardens to health remains confined within two particular scopes. The first one is that of nutrition. Homegardens are regarded as one strategy for addressing malnutrition and causes of micronutrient deficiencies [41-47]. The second scope is herbalism through the provision of medicinal plants $[13,48$ $50]$.

To contrast with these standard ways of addressing the contribution of homegardens to human health, I wish to adopt a totally unexplored perspective to assess their function as an integrative feature of healthy well-being. Using an ethnobiological approach, my goal is to demonstrate how the spatial assemblage around or near houses acts as an ultimate means to prevent exposures to diseases. The demonstration is based on fieldwork carried out among the Fang speaking forest dwellers of Central African Congo Basin. The spaces that are the focus of this discussion are parts of the dwelling 
environment and form two antagonist poles of activities, representations and values. These two poles - named with the antinomic terms 'courtyard' and 'backyard' - are inseparable and complementary elements of the social and ecological systems: one cannot apprehend the characteristics of one pole without simultaneously considering the symmetrical functions of the other pole [51]. As I wish to stress, the cultural control of risks on health does not only concern the physical and functional layouts of the landscape-aimed at reducing the incidence of vector-borne and transmissible diseases-but it also concerns the symbolic control of supernatural forces, which are much less immediately tangible causes of sickness, pain, trouble, conflict and even death. An extensive exploration of the existing literature on homegardens (nearly 300 references were compiled) has revealed no similar attempt of analyzing the multidimensional-ecological, spatial, social, historical, linguistic, symbolic - structure of homegardens in terms of health risks avoidance.

\section{MATERIALS AND METHODOLOGY}

\section{The Study Area}

The Bantu people referred to as 'Fang' in this paper form a continuum of five ethnic groups - namely the Fang sensu stricto, the Mvae, the Nzaman, the Ntumu and the Okakwho all speak a Fang language. They constitute a single linguistic sub-group, which is termed 'Fang' and is characterized by a mutual comprehension between speakers.
These ethnic groups are mainly located in the southern part of Cameroon and they total around 40,000, scattered widely and mixed with other linguistic groups over a province covering 47,000 square $\mathrm{km}$ (Fig. 1). There are also significant Fang populations in Equatorial Guinea (55,000 Fang speakers) and northern Gabon (150,000). The Fang are basically slash-and-burn swidden farmers who also trap and fish. Their main sources of income are bushmeat trade [52], sales of food crop surpluses [53], and cash-crop plantations mainly based on cocoa [54].

Before the second half of the seventeenth century, the Fang ethnic groups were widely known as fierce and nomadic warriors who originated east of their current territory near the source of Ntem and Ivindo rivers. Their migrations to lands currently included in southern Cameroon were motivated by a search for salt, which was to be found towards the Atlantic coast. Fang migrations occurred as diffuse and irregular step-by-step relocations by extended family groups who punctuated their progression with local and repeated skirmishes. This migration was interrupted by colonial penetration from the coast during the second half of the seventeenth century. This colonial penetration marked the beginning of Fang involvement in the trade of forest resources-ivory and copper-and their role as raiders of potential slaves. During these conflictive times, the Fang were renowned for their exceptional fierceness and barbarity, and their villages were, more than among other ethnic groups, organized to better respond to unremitting conflicts. Hamlets were based on small political communities corresponding to extended families (mvók à bót) and were

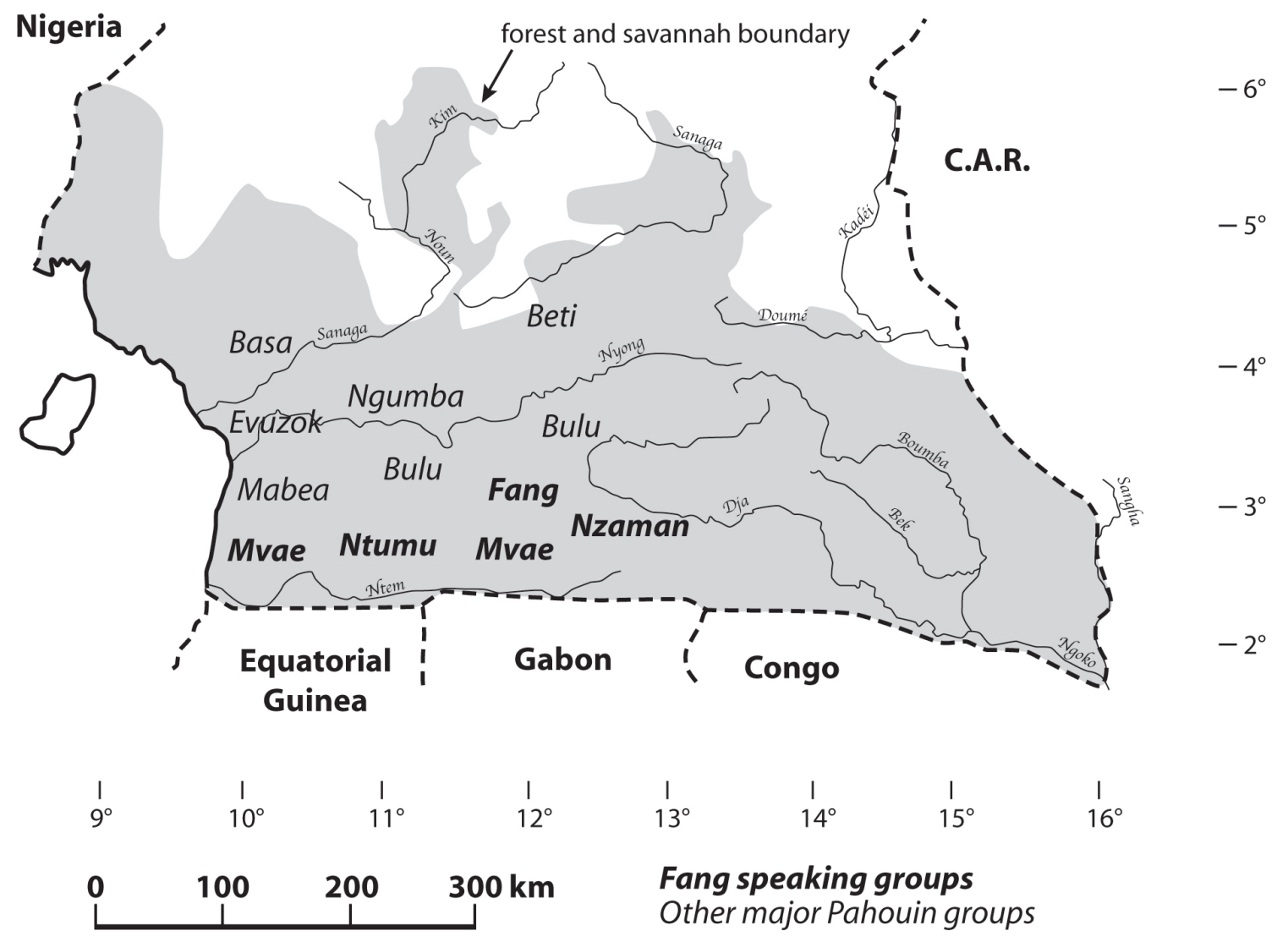

Fig. (1). Distribution of Fang speaking forest dwellers in Southern Cameroon (C Dounias 2009). 


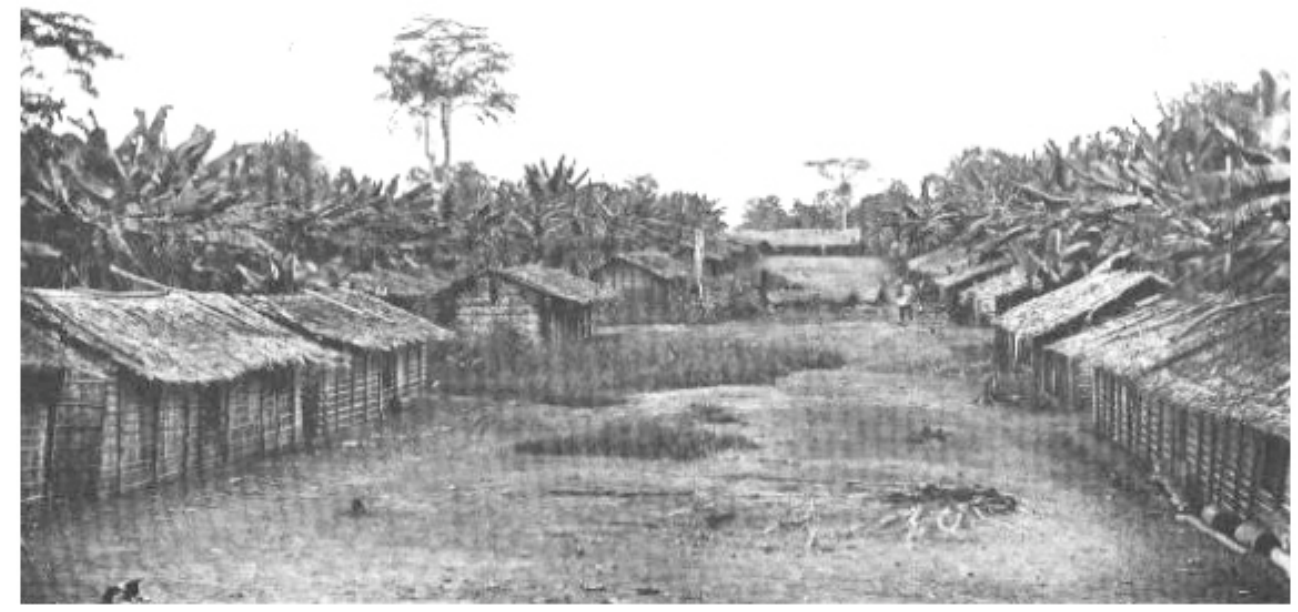

Fig. (2). Typical Fang homegarden (reproduced from Cureau 1912).

spatially assembled around the men's house or guardroom (à.báa ), which was located at the entrance of the village to ensure protection (Fig. (2) [55]). Houses were distributed along two parallel lines (im.mbàmà) and shared a single central courtyard (ń.nsEy). Each house (ndà) had a front door, and another one that was situated à fâlàk, (lit. "along the back wall") which was meant to be the safest part of the house. This 'exit door' offered quick access to the backyard (fàlàk). Enemies would not approach through the backyard nor pursue runaways into it because they feared the traps and countless magical protections that were hidden in this anthropogenic undergrowth.

The spatial organization of the hamlets thus appears as an efficient response to regular warfare (Fig. (3) [56]).
However, the opposition between courtyard and backyard cannot be reduced to just military considerations: it also finds its source in profound - thus less immediately perceptible - socio-cultural drivers. A hint that this sociocultural dimension is a significant determiner is that the courtyard/backyard dichotomy has survived the pacification imposed by the colonial administration in the late nineteenth Century. Nearly one hundred years after pacification, it continues to be a fundamental component of Fang villages.

The dichotomic structure of Fang homegardens is only one component of a broader conceptualization of their physical environment, which is organized around a series of dichotomies that are nested like Russian dolls. Firstly, the typical Fang village $(d z y \hat{a})$ is defined through its

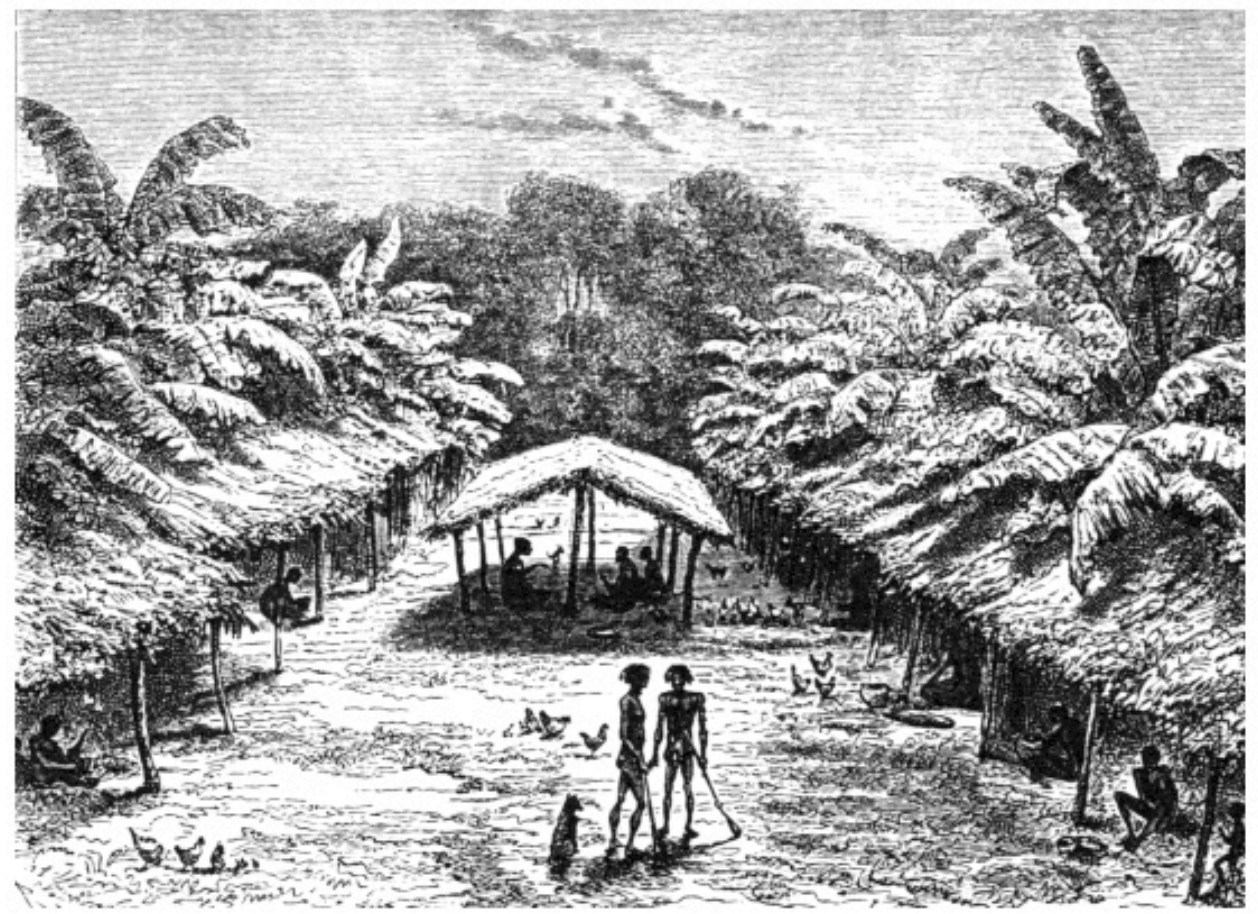

Fig. (3). Spatial organization of Fang hamlets as a means to regular warfare (reproduced from Compiègne and Marche 1874). 
fundamental opposition to the forest (áfân). The dzyá is a portion of forest, which has been borrowed by humans after careful negotiation with the forest spirits: opening a swidden, trapping game, catching a fish or harvesting a wild plant would not be possible without the agreement of supernatural forces, which exert control over all life forms. The dzyá is a human enclave, which must be perpetually renegotiated with the forest spirits through a complex-though vanishingcult of the ancestors.

The Fang village $(d z y a \hat{)})$ is in turn composed of two basic and opposed units: the residential area (ì.nàm) is composed of houses and their immediate surroundings; the opposite unit is called fén. The h̀.nàm is a social area where villagers live and undertake domestic activities. The $f \mathscr{\varepsilon} \eta$ is the production area, which encompasses the swiddens, young fallows and various types of post-agricultural secondary regrowths. In contrast to the permanency of the ni.nàm, the $f \mathcal{E} \tilde{n}$ is spatially more ephemeral. Human ascendancy over this part of the land is formalized by shifting cultivation; in essence, it is temporary and must be regularly displaced [54]. The constant move of swiddens does not only provide the advantage of reducing competition between crops and pets and avoiding time costly weeding activities. Furthermore, farmers and their families who spend a significant amount of time in their distant swiddens that are scattered in the forest, are seldom exposed to diseases that need a critical mass of concentrated hosts in which to propagate [57].

The ìnàm is organized around the two complemen-tary spatial units that form the central topic of this paper: the courtyard (ń.nsEn), and the backyard (fâlàk). In between these two opposed components of the homegarden, is a sort of buffer zone composed by the homestead area (ndàbót). The ndàbót is the man's compound, and is composed of the main house (ndà), related kitchens (kǐszn) and surrounding small gardens (ngàràn). The ndàbót also refers to the fundamental economic unit in Fang societies.

\section{METHODS}

The data used in this paper were obtained during field studies that were carried out in parallel among different Fang speaking groups (in priority among the Mvae, and more extensively among the Ntumu and the Nzaman) between 1984 and 1998. Methods used for data collection were taken from different disciplinary approaches: nutrition, geography, ecology, history, anthropology and ethnobiology. In 198485 , a quantitative food consumption survey was conducted among 40 Mvae families using a standard weighing technique. More than 4,100 preparations were sampled on a seasonal basis; they served to characterizing the effective contribution of homegardens to the diet. Household interviews were used during time-series household surveys to collect data concerning the socio-economic use of homegardens. In 1990-91, I monitored the sources of income and activities of all the households (11 in total) of a small Mvae village (Nkoelon) situated at the periphery of the Campo Faunal reserve in coastal Cameroon. This monitoring included a systematic recording of hunted game, and specifications regarding the location of capture, hunting procedures, identification of hunters, and the destination of game meat [52]. Socio-economic data were complemented by an extensive exploration of literature and archive documents regarding the history of Fang speaking groups that were compared with the local oral tradition, and by the collection of anthropological data on landscape perception and uses-through numerous unstructured interviews of villagers.

I also carried out systematic ethnobotanical surveys on the main plants (domesticated, ruderal, wild) that contribute to local economy. A dozen villages were mapped: vegetation in the courtyard and near dwelling houses were exhaustively identified and counted. I analyzed into more details a sample of six backyards (the size of which varied between 2.0 to 5.3 hectares) in four distinct Mvae villages, using the method of 3D profile to quantify their spatial structure and floral composition. Tree densities were estimated and most tree species were identified. Backyard owners were interviewed on the names of the trees, their potential uses, and recognized properties. They were also invited to specify the origin of each individual tree: native versus exotic, planted (or transplanted) versus preserved (or spontaneous). Plants with other habits (lianas, shrubs, herbs) were also inventoried (without systematic counting).

\section{RESULTS}

\section{Bare Soil in the Courtyard, Dense Agroforest in the Backyard}

The visitor who enters a Fang village is immediately struck by the scarce vegetation of the courtyard, which strongly contrasts with the dense vegetation behind the houses. In fact, fewer than three per cent of the total plants growing inside the habitat perimeter are located in the courtyard. The soil of the courtyard is clear of weed cover and totally exposed to sunlight. One of the reasons for avoiding the development of vegetative cover is to prevent the proliferation of undesirable animals (parasites, ticks, sand flies, tabanid flies, herbivores, snakes, weaver birds). Having a wide deforested area also decreases the number of spontaneous seedlings and minimizes the chances for dense vegetation to recover as birds and other seed dispersers are strongly discouraged from flying over or running through such large open spaces. Maintaining an even soil surface, free from vegetation and other debris puts off snakes, scorpions and venomous spiders; it also prevents puddles and thus limits the proliferation of mosquitoes.

Only a very few trees-literally called 'trees of courtyard' (èlé ya ń.nsEn) - provide a semblance of shade immediately in front of houses. These trees are mainly palm trees (Cocos nucifera L., Elaeis guineensis Jacq., Phoenix reclinata Jacq.), flowering trees (listed below) and, less frequently, small trees bearing fruits such as guayava (Psidium guayava Raddi), soursop (Annona muricata L.), avocado (Persea americana Mill.), calabash (Crescentia cujete L.), papaya (Carica papaya L.), mango (Mangifera indica L.), and African pear (Dacryodes edulis (G. Don) H.J. Lam). The Fang advance several proximate reasons for the rarity of fruit trees in the courtyard. Firstly, they report that the fruits are damaged when they fall on the bare soil whereas in the backyard, their fall is softened by ground cover. Secondly, the bare soil of the courtyard causes 
increased surface erosion during heavy rains leaving the superficial roots of trees exposed, which may negatively affect their production. Maintaining fruit trees in the courtyard requires the installation of fenced earthworks at the base of each tree. Lastly fruit trees seldom have diffuse crowns: Citrus trees, which have a dense crown (ì.ntùù), and banana trees can harbor snakes and Dorylus weaving ants and are therefore always planted backyard. The benefit on health is never advanced as a prior argument.

Another important component of courtyard vegetation is a plot of ornamental plants called literally 'field of flowers' (à.fúp ná sàm). The tallest flowering trees contribute some shade-e.g., Santiria trimera (Oliv.) Aubrév., Spathodea campanulata P. Beauv., Delonix regia (Bojer ex Hook.) Raf., Plumeria rubra L., several Apocynaceae like Alstonia boonei De Wild., Rauvolfia spp. L., Funtumia elastica (Preuss) Stapf, Voacanga sp. Thouars, Thevetia peruviana (Pers.) K. Schum.-but the great majority of ornamental plants are small trees or shrubs-e.g., Bixa orellana L., Datura sp. L., Caesalpinia spp. R. Br., Cordyline terminalis (L.) Kunth, several Euphorbiaceae like Breynia disticha J.R. Forst. \& G. Forst., Codiaeum variegatum (L.) Rumph. ex A. Juss., Pedilanthus tithymaloides (L.) Poit. In addition to making the courtyard more welcoming by virtue of their visible and decorative flowers, ornamental plants act as strong repellents to vectors of diseases and levels. Almost all ornamental plants are rich in toxic secondary compounds or exude unpleasant latexes that discourage unwanted herbivores, flies and weavers from taking up residence nor laying their eggs in them. Last but not least, these plants have a positive psycho-cultural influence that contributes significantly to the well-being feeling of the villagers (Fig. 4).

To summarize, exception for a few fruit trees, the woody plants that compose the vegetation of the courtyard are usually small, and, if tall, they have a diffuse and light crown. They are largely composed of introduced species, which underscores the profound interest of these horticulturalists in experimenting with new plants, their insatiable quest for novelty and their unremitting concern to make this space as attractive as possible. Lastly, the preference for ornamental plants suggests a selection favoring plants that have a deterrent effect on vectors of diseases.

Backyard vegetation offers a striking contrast with that of the courtyard. Although it is a domestic space, the continuous canopy creates a habitat that mimics the natural forest. In fact, the backyard is a dense agroforestry system, which contains more than 72 per cent of the plants in the village. This multi-strata agroecosystem has plants of all growth habits [20]. In contrast to the courtyard, the backyard agroforest has a high density of useful plants and multipurpose trees that provide food, firewood, materials for construction and manufacture, as well as medicinal and magic plants. The majority of the species found in this space are natives, but exotic (thus intentionally planted) plants dominate in number of individual plants. The Fang constantly experiment with and acclimatize new exotic plants and crops in the backyard. Such experiments are very discrete and always intervene in a private context.

The immediate 5 to 10 meters around the house offers an intermediate situation between the courtyard and the

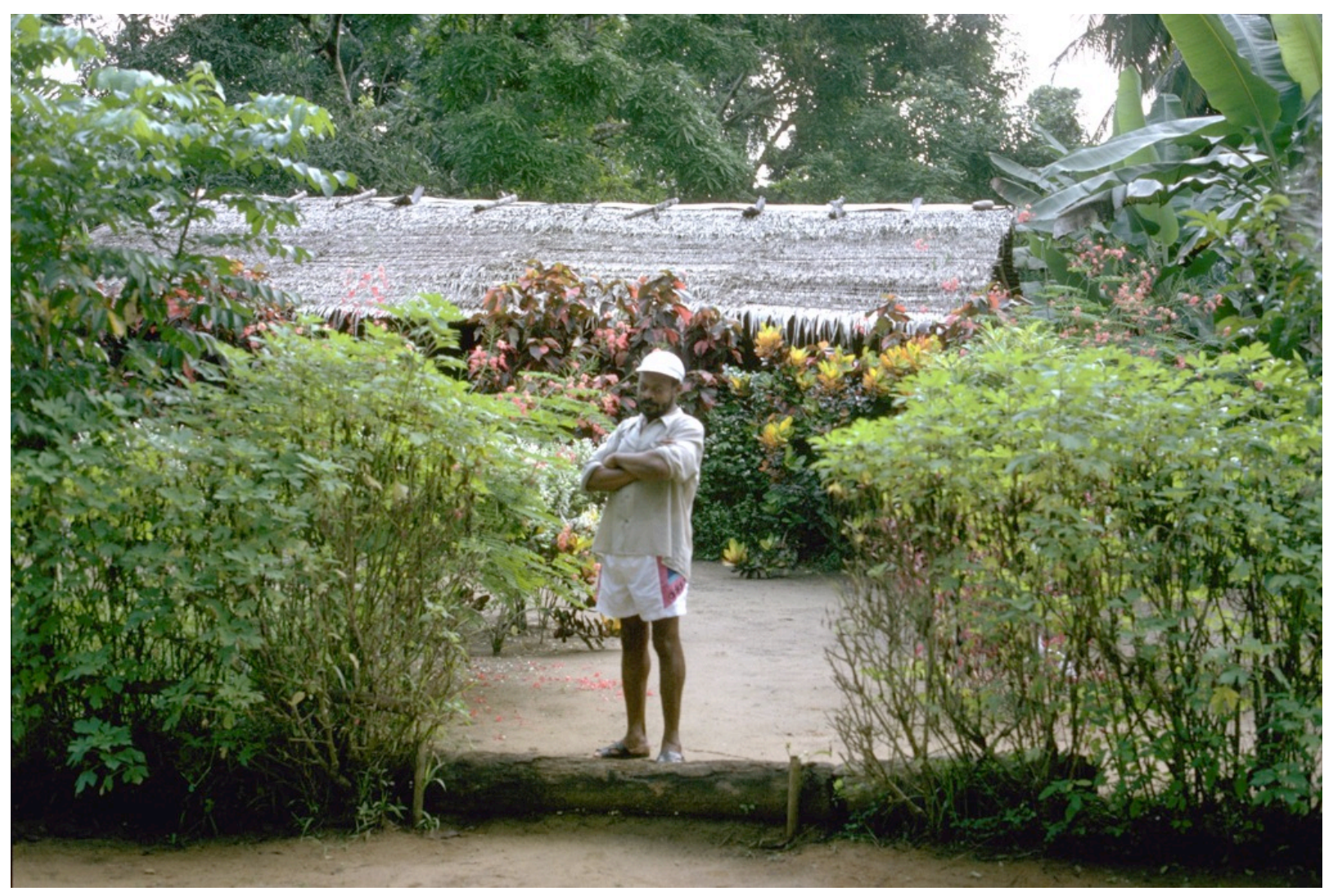

Fig. (4). Ornamental plants in the courtyard (C Dounias 1986). 
backyard. This small area has about $25 \%$ of the total individual plants that grow in the domestic space. Nearly 125 different plant species were reported during my interviews with Fang villagers. As published elsewhere [53], about 25\% are ornamental or magical protective individual plants, another $25 \%$ are ruderal individual plants and the remaining $50 \%$ are fruit trees and foods crop: tubers, vegetables and, most importantly, spices, condiments, flavorings, seasonings. These latter plants are now widely admitted as inhibitors of food spoilage microorganisms. This property is supported by their richness in antimicrobial secondary compounds [58]. The palatability of such plants to herbivores is also drastically reduced and besides their role in cleansing food of pathogens, they also cleanse the houseyard of unwished rodents [59]. Wild plants - ruderal excluded - are manifestly absent and the plants cultivated in the homestead area require light shade.

\section{Livestock in the Courtyard, Wildlife in the Backyard}

Livestock are an important asset as animals may be sold to quickly satisfy a need for cash, for instance during hospitalization, but livestock mainly serve for social events. They are involved in dowry exchanges, and are sacrificed during marriages, funerals, religious celebrations, rites of passage and other ceremonies. The open, protected, pest-free courtyard provides an ideal location for keeping livestock. Sheep, goats, ducks, chicken and, to a lesser extent, pigs circulate freely in the courtyard and the homestead area where they are easily observed by their owners, who ensure that no animal is missing or has a problem (injury, disease). The ground cover of the nearby homestead area and the edge of the backyard vegetation give out food for the livestock and receive in return animal droppings that help to restore the soil fertility (Fig. 5). Livestock do not spend the night in closed buildings; these animals would otherwise more easily attract nocturnal predators. They spontaneously merge along the walls of house in search for warmth, and serve as indirect attractors of blood sucking insects, thus diminishing insect bites over humans during their sleep.

The backyard forms an efficient barrier against livestock predators that are discouraged from venturing onto the courtyard. In return, the backyard also serves as a natural fence to prevent livestock from wandering into the distant fields. Most importantly, however, the backyard is rich in wild animals, which tolerate the proximity with humans and which find in the vicinity of human houses an environment that is low in natural predators. This forest-like environment offers them optimal conditions to reproduce. These species, mostly large rodents-greater cane rat (Thryonomys swinderianus Temminck), giant rat (Cricetomys emini Wroughton), crested porcupine (Hystrix cristata Linnaeus), forest giant squirrel (Protoxerus stangeri (Waterhouse), flying squirrel (Anomalurus spp. Waterhouse), brush-tailed porcupine (Atherurus africanus Gray) - , are a valued source of meat and are too prolific to be seriously endangered by hunting pressure. They do not compete for food resources devoted to livestock. Traps are installed along the network of paths that lead through the backyards to water sources, swiddens, and other productive areas. The total absence of contact between livestock and wildlife (confined in courtyard and backyard respectively) regulates the potential transmission of zoonotic diseases to livestock that may eventually transmit them to villagers.

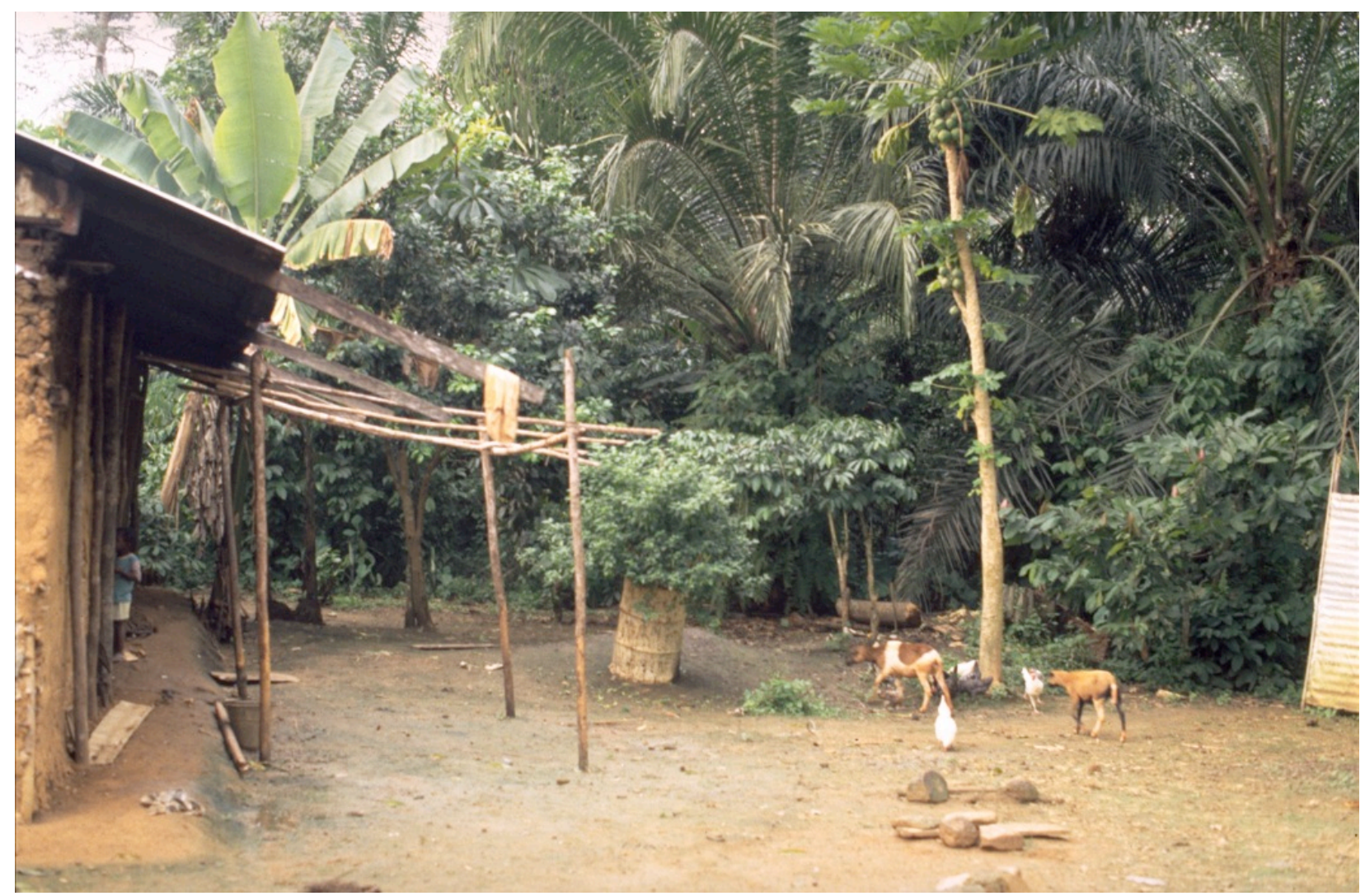

Fig. (5). Free circulation of livestock in the courtyard and near dwelling houses (C Dounias 1996). 


\section{Obsessive Cleaning of the Courtyard, Detritus in the Backyard}

The Fang devote a significant amount of time to cleaning, weeding and removing useless roots and stumps from their courtyard. The sound of the broom on bare soil in the front of the house is the first sign of human activity in the early morning. Everybody, including the male heads of household, participates in this task. In ancient times, it was even an exclusive male task: the head of the village-dressed in ritual uniform-would sweep the courtyard early before sunrise, while other villagers were still sleeping [60]. This detail initially seems unusual in a patrilinear society but should not be viewed as degrading or as a lack of authority. Actually, sweeping the courtyard does not only consist of removing garbage and animal feces, thereby preventing vermin (sand flies, skin maggot flies), but it also symbolically removes importunate spirits.

In the front of houses-directly under the roof or in shade trees planted in the front-the Fang also hang containers to gather clean rainwater. Some courtyard trees with an appropriate architecture (e.g., Terminalia catappa L., Bauhinia sp. L.) are even specifically planted to serve as receptacle for rainwater containers. These trees are also used for hanging washed clothes out to dry. Direct exposure of clothes to heat and sun efficiently prevents from the skin maggot fly (Cordylobia anthropophaga Blanchard) that lays its eggs on wet clothes and soils. This fly, that is the most common cause of human myiasis in tropical Africa [61], can hardly reproduce under such circumstances.

The treatment of the backyard is totally opposite. In contrast to the care given to each of the plants growing in the courtyard, the backyard agroforest looks more like a vegetative mess. This space receives the cooking garbage and all the debris that is carefully swept away from the courtyard. The backyard also benefits from the natural fertilization by fallen leaves and the feces of wildlife, rambling livestock and humans. Each Fang village counts several toilets, which are always located in the backyard, at a short walking distance from the first houses. Oral tradition holds that the Fang attached singular importance to the construction and maintenance of their toilets. It was a chief's duty to regularly inspect the state of the toilets and inflict sanctions if they were not kept sufficiently clean. The evident goal of this long tradition to keep toilets away from houses was to limit fecal pollution.

\section{Male Authority in the Courtyard, Women Antrum in the Backyard}

From the origins, the guardroom ( $\grave{a} . b a ́ a ́)$ was a building of major importance in the village around which the residential group was organized. This defensive structure was, in essence, a male space. In today's pacified climate, the guardroom functions as a social space for men. The men's house is a place for rest and relaxation, where all the men of the village converge at the end of the day, after having finished their activities outside of the homestead. They play songs - a very popular game in Central Africa-, weave or carve tools and implements, exchange news and tell stories. This is also where visitors are formally welcomed so all the villagers can be informed about the reason for their visit. Unwished guests are "filtered" there: foreigners are not admitted to circulate in the village unless they obtain formal authorization by the men at the guardroom. The customary tribunal officiates in the men's house, as well as any negotiation that requires consensus from the whole village.

The men's house is also the appropriate place for men to share their meals. At noon, they consume a snack made of vegetables and, more symbolically, of bulbils of Dioscorea bulbifera L. The rounded aerial tubers of the cultivated form of this yam species are edible, but can be easily confused with the poisonous bulbils of the wild form that grows spontaneously in forest edges and young fallows. If anyone intends to poison someone else by substituting toxic wild bulbils, he exposes everybody, including himself, to sickness or death. Thus sharing this dish symbolizes trust between the parties and affirms the healthy social relations between all the members of the village.

The backyard is undoubtedly female domain. The main access to the backyard is via a door from the woman's kitchen, and the erstwhile role of the backyard as an escape route in case of attack was for the benefit of women and their children. Women are in charge of spreading or disposing of domestic waste in the backyard and gathering firewood. They also tend the plants in the kitchen garden and the nontimber forest products that grow in the undergrowth. More importantly, women take care of countless medicinal plants that are hidden in the backyard and are used to treat children's diseases and reproductive disorders.

Until recently, Fang women gave birth in the backyard, under the protection of charms that dissuaded aggressive sorcery [62]. After delivery, the mother buried the placenta in a secret location of the backyard and without leaving a visible mark of any sort, thereby hiding the placenta from witches. If the infant happens to die shortly after birth, the mother will check the spot of placenta burial again, to make sure that no potentially malevolent person had dug it out without her knowing it. Today, Fang women no longer give birth in the backyard. Nevertheless, they persist in burying the placenta there and respecting a period of seclusion after child delivery, during which the mother and her child are physically weak and consequently exposed to witchcraft aggressions. The seclusion chamber is always set up à falàk, along the back wall of the kitchen, the most secure place within the house.

\section{Smiles in the Courtyard, Crimes in the Backyard}

The courtyard is undisputedly a public space that is dedicated to healthy social interactions. It is expected to be a pleasant place that must appear friendly and warm to visitors. Access to the doors of each house is totally clear. It is a common practice to speak loudly in the courtyard, often laughing, and sentiments are often communicated with effusion and, sometimes, exaggeration. All festive events and their related dance, music, food and other recreational performances, take place in the courtyard. Formal communication often occurs in the courtyard: this is where the Fang stage the tribunal forum. The calling drum sits on a special tripod or platform, or it is sometimes hung in a tree so that its sound will carry further. The courtyard mobilizes 
significant time and energy to maintain a space that is dedicated to pleasure, decoration, leisure, and resting; as such, it can be considered a space of consumption.

The backyard, on the other hand, can be considered a private and even, to some extent, unfriendly space. It is worth noting that a village is composed of a single common courtyard, while each man's compound has its own backyard. Access to backyards is not completely forbidden but it is implicitly restricted or, more accurately, discouraged. The backyard is known to be full of magical components from vegetal, animal and mineral sources that are hidden in the ambient vegetative 'mess'. In times of war, the fear of hidden protection charms effectively protected the flight of women and children, a deterrent effect against witchcraft, which persists today. The backyard is a space of production and hard work. People move in it with discretion, adopt a humble demeanor and generally speak quietly. It is also the ideal spot to make a promise to someone, to share a secret and to hide precious goods. Finally, the Fang consider the backyard to be the domain of a certain form of wealth: not à.kümá, which refers to the material possessions that one exhibits with great pomp in the courtyard or in a man's compound, but rather némE, which evokes wisdom, knowledge, and which also connotes the capacity to communicate with spirits (bjkj́n) and to benefit from their good graces.

\section{Festive Celebrations in the Courtyard, Occult Rites in the Backyard}

The adoption of Christianity is an ongoing process that began with the encounter between the Fang and colonial migrations along the coast almost 200 years ago. Today, a majority of the Fang are Christians and this official worship is practiced with maximum visibility and devotion in the courtyard. All festive and religious ceremonies that respect the Christian calendar take place in the courtyard.

When a member of the community dies, the family convenes in the courtyard and the body of the deceased is openly and publicly prepared for burial. If the deceased is a child, a woman or a man without special status or powers, the body will be rapidly buried in the backyard, but the funeral banquet and all other post-funeral related ceremonies will be performed in the courtyard. If the deceased is a great man, burial will be differed until distant relatives and distinguished guests converge to the village to attend the funerals. In this particular case, the body will be confined in a marginal room and a set of plants including Piper umbellatum L. and Cymbopogon citratus (D.C.) Stapf will be used-via fumigation, injection and other embalming practices-with the specific scope to delay the decomposition of the corpse.

Fang ritual life is extremely rich and is marked by several initiation procedures that are a prerequisite for entering various secret societies. These rites have fascinated several generations of anthropologists and have been minutely described elsewhere [60,63-67]. Although weakened today by missionary activity and government prohibi-tion, Fang pagan cults endure. Nevertheless, they are now confined to the discreet environment of the backyard. Witchcraft and sorcery are condemned by the church and denounced during public condemnations of persons who are suspected of devoting themselves to such forbidden practices. The tribunal, which passes down these judgments, officiates in the courtyard. However, such visible and unanimous sentencing hardly dissimulates the evidence that witchcraft dictates the daily life of the Fang and profoundly conditions their social relations. The Fang have concluded that there are several sorts of people according to whether they do or do not possess the witchcraft being $(\grave{e} . v \hat{u})$ a sort of immaterial force that predestines one's capacity to have good fortune throughout life. The Fang then couch their discussion of witchcraft in the terms of personal ambition and the search for wealth and glory. Those who have a strong $\grave{e} . v \dot{u}$ are true witches. The $\grave{e}$.vú is wont to leave the body and to cast a spell on someone else in order to benefit its possessor. It subsists on the blood and flesh of mankind and is thus something of a cannibal.

In ancient times, several anti-witchcraft secret societies actively counteracted witchcraft, and so did the ancestors. Ancestors were believed to desire harmony among living people and the cult dedicated to them exerted controls upon egoistic and aggressive forces [63]. The Fang credited a great deal of personal misfortune to the ancestors and explained it as a consequence of ancestor dissatisfaction with some filial impiety of their descendants. A cult to the ancestors (melan) was elaborated through the veneration and conservation of skulls and reliquaries (byiéri) symbolizing protective spirits that were carefully kept in the backyard. When someone was suspected of sorcery, s/he was forced to drink poison in public in the courtyard, as an ordeal to prove his/her innocence. If $\mathrm{s} / \mathrm{he}$ died, his/her body was carried to the backyard and was autopsied in order to confirm his/her guilt. Persons who died of suspected bewitchment were also autopsied in the backyard as the $\dot{e}$.vú is known to devour the entrails of its victims $[65,66]$.

Women had their own secret societies, which have persisted much better than the male ones, probably because they were devoted to protection against recurrent sterility or reproductive troubles $[68,69]$. Women perform rites in the backyard that unambiguously celebrate the female genitalia and force.

\section{DISCUSSION}

As recapitulated in Table 1, homegardens are multipurpose entities that make a contribution far greater than encompassing a host of functions and beliefs that contribute to ecology, economy, diet, ritual life, remedy, self-reliance, privacy, nostalgia, or agrarianism [48].

Courtyard and backyard are fundamental and bipolar features of the habitat of most forest dwellers in Central Africa. But these land uses represent more than just physical and spatial entities. They also constitute powerful cultural poles. Beyond their pragmatic roles as unique components of the land use system that undoubtedly contribute to household economy and biodiversity conservation [20], courtyard and backyard fulfill a series of opposed functions that mark out the life history of the Fang, the social relationships between the different members of the communities and the symbolically rich settings for everyday life and rituals. As such, they are a manifest representation of the community's 
Table 1. Synthesis of Courtyard/Backyard Dichotomy and Related Benefits on Health

\begin{tabular}{|c|c|c|}
\hline Frontyard & Backyard & Benefits on health \\
\hline \multicolumn{3}{|c|}{ Biotic characteristics } \\
\hline Poor vegetation & Dense agroforest & \multirow{4}{*}{$\begin{array}{c}\text { Control of vegetation and shade; dryer space; fewer blood sucking insects; fewer } \\
\text { venomous animals; less puddles, less mosquitoes }\end{array}$} \\
\hline Domesticated plants & Spontaneous plants & \\
\hline Shrubs and small trees & All biological types & \\
\hline Bare soil & Multi-stratified undergrowth & \\
\hline Palm and fruit trees & Multipurpose trees & \multirow{3}{*}{$\begin{array}{l}\text { Sources of food and medicines; psycho-cultural well-being; antimicrobial } \\
\text { properties and cleansing food; repellent on herbivores and biting insects; testing } \\
\text { new medicines }\end{array}$} \\
\hline Visible and ornamental plants & $\begin{array}{l}\text { Hidden magical and medicinal } \\
\text { plants }\end{array}$ & \\
\hline $\begin{array}{l}\text { Spices, condiments, } \\
\text { flavorings, seasonings }\end{array}$ & $\begin{array}{c}\text { Experimentation and } \\
\text { acclimatizing new plants }\end{array}$ & \\
\hline Only lightly crowned trees & Continuous canopy & Regulating undesirable animals (snakes, weaving ants, biting insects) \\
\hline Livestock & Wildlife & $\begin{array}{l}\text { Livestock diverts blood-sucking insects; it meets a sudden need for cash like, for } \\
\text { instance, during hospitalization. }\end{array}$ \\
\hline $\begin{array}{l}\text { Free circulation of animals, } \\
\text { absence of confinement }\end{array}$ & Natural fence & Avoiding predators; limiting transmission of zoonotic diseases \\
\hline $\begin{array}{l}\text { Animals sacrificed for } \\
\text { ceremonies }\end{array}$ & Garden hunting, children snacks & Sources of meat (ritual food, nutrition) \\
\hline \multicolumn{3}{|r|}{ Maintenance } \\
\hline Swept and cleaned soil & Vegetal mess & $\begin{array}{l}\text { Limited risks of contamination; preventing vermin; sweeping away unwished } \\
\text { spirits }\end{array}$ \\
\hline Gathering of rainwater & Detritus/cooking wastes & Clean rainwater for drinking \\
\hline Hanging of washed clothes & $\begin{array}{l}\text { Natural fertilization by livestock } \\
\text { feces }\end{array}$ & Clean clothes; preventing dermatosis and myiasis \\
\hline $\begin{array}{l}\text { Careful weeding and } \\
\text { uprooting }\end{array}$ & Toilet & $\begin{array}{l}\text { Mitigation of fecal pollution; avoiding injuries and domestic accidents on roots } \\
\text { and stumps }\end{array}$ \\
\hline Non deciduous vegetation & $\begin{array}{l}\text { Humus and fallen leaves } \\
\text { (fertilization) }\end{array}$ & Controlled accumulation of detritus \\
\hline \multicolumn{3}{|c|}{ Social life and gender division } \\
\hline Public space & Private space & \multirow{11}{*}{$\begin{array}{l}\text { Social justice to maintain healthy social relationships; giving birth in good } \\
\text { conditions; period of seclusion after child delivery; balance between collectivism } \\
\text { and privacy; avoiding bewitchment; obligation of sharing as a means to reduce } \\
\text { poisoning; facilitated escape of women and children during war times; women take } \\
\text { care of medicinal plants to treat children's diseases and reproductive disorders }\end{array}$} \\
\hline Pleasing space & Unfriendly space & \\
\hline Free access & Restricted access & \\
\hline Welcome & Dissuasive & \\
\hline Space of consumption & Space of production & \\
\hline Resting and recreational space & Busy place & \\
\hline Speak loudly & Speak quietly & \\
\hline Effusion & Discretion & \\
\hline Men salon & Women sphere & \\
\hline Festive activities & Discreet activities & \\
\hline Food sharing & & \\
\hline \multicolumn{3}{|r|}{ Spiritual life } \\
\hline $\begin{array}{l}\text { Christian authorized cult and } \\
\text { ceremonies }\end{array}$ & Pagan prohibited cults & \multirow{4}{*}{$\begin{array}{l}\text { Control of contamination by dead corpses; avoiding witchcraft, misfortune, } \\
\text { aggressive supernatural forces; protection against sterility and reproductive } \\
\text { troubles; cult for the ancestors to maintain harmony among living people; } \\
\text { customary tribunal to condemn sorcery. }\end{array}$} \\
\hline $\begin{array}{c}\text { Ostentatious tombs of great } \\
\text { men }\end{array}$ & $\begin{array}{l}\text { Discrete tombs of children and } \\
\text { women }\end{array}$ & \\
\hline Tribunal, harangue & Witchcraft and sorcery & \\
\hline Preparation of funerals & $\begin{array}{c}\text { Autopsy to track down } \\
\text { bewitchment }\end{array}$ & \\
\hline
\end{tabular}

most deeply held values that guarantee well-being and the resilience of the entire livelihood.

The different aspects-ecological, spatial, social, symbolic, gender division-of Fang life-style that are mobilized near and around habitat reveal that the bipolarity of Fang homegardens acts as a cultural means to regulate the risk of contracting a disease, be it of natural or supernatural origin. Control of health risks is certainly not the proximate 
reason for this binary opposition to exist. Nevertheless, the many interactions between social, cultural, political, historical, and ecological features combine to provide an ultimate evolutionary benefit in terms of disease regulation [70]. This cultural management of the risk does not only concern the physical and functional layouts of the landscape, that are bound to reducing the occurrence of zoonotic, vector-borne and transmissible diseases, controlling the proliferation of pests, easing child delivery, or minimizing post-mortem infections, as well as maintaining healthy social relationships and preventing witchcraft and malevolent intentions. It also entails the symbolic control of supernatural forces which, for the outside observer, are much less immediately tangible causes of sickness, pain, trouble, conflict and even death. In that respect, through their persistent secret societies, women who are in charge of the backyard, endorse a fundamental role in maintaining a healthy environment for the entire community.

Fang homegardens are in fact spatial projections of the perception that Fang ethnic groups have of themselves. Assessing such an emic perception of the relations between the Fang and their natural environment necessitates historical contextualization. Pertinent local historical factors - warfare and inter-village disputes, Christianization and resilient witchcraft beliefs, balance in gender powers and functions within communities and through reminiscent secret societies, mitigation of health related risks and more recent environmental change - provide a good safeguard against excessively deterministic interpretations of the ecological and economical services lavished by homegardens. Unfortunately, such services are too often overoptimistically put forward as a panacea to mitigate biodiversity loss and alleviate poverty [4,66,71-73]. They eventually overshadow countless other functions and complex cultural dimensions, and may engender misleading development initiatives [51]. Homegarden-based land-management initiatives would gain in transcending such immediate 'money as usual' concerns by encompassing the whole bunch of biocultural interactions into play and by promoting less immediate and less obvious constituents of well-being. The ultimate advantage of controlling health risk is revealing of such necessity to look outside of the narrow box of productivity and profit.

\section{NOTES}

Vernacular terms correspond to Mvae language (Dounias 1993). 'and 'accents refer to upper and lower tones respectively and absence of accent corresponds to a medium tone. The prefix - separated from the word root by a full stop - is a mark of singular/plural.

\section{REFERENCES}

[1] Terra GJA. Mixed-garden horticulture in Java. Malayan J Trop Geogr 1954; 1: 33-43.

[2] Landauer K, Brazil M, Eds. Tropical home gardens. United Nations University Press: Tokyo 1990.

[3] Hoogerbrugge I, Fresco LO. Home garden systems. Agricultural characteristics and challenges. London: IIED 1993.

[4] Mitchell R, Hanstad T. Small home garden plots and sustainable livelihoods for the poor. Roma: FAO 2004.

[5] Christanty L. An ecosystem analysis of West Javanese home gardens. Honolulu, Hawaii: East-West Center 1981.
[6] Christanty L. Home gardens in tropical Asia, with special reference to Indonesia. In: Landauer K, Brazil M, Eds. Tropical home gardens. Tokyo: UNU Press, 1990; pp 9-30.

[7] Abdoellah OS. Home gardens in Java and their future development. In: Landauer K, Brazil M, Eds. Tropical home gardens. Tokyo: UNU Press, 1990; pp 69-79.

[8] Michon G, Mary F. Transforming traditional home gardens and related systems in West Java (Bogor) and West Sumatra (Maninjau). In: Landauer K, Brazil M, Eds. Tropical home gardens. Tokyo: UNU Press, 1990; pp 169-85.

[9] Kehlenbeck K, Maas BL. Crop diversity and classification of homegardens in central Sulawesi, Indonesia. Agroforestry Syst 2003; 63: 53-62.

[10] Benoît C. Corps, jardins, mémoires: Anthropologie du corps et de l'espace à la Guadeloupe. Paris: MSH 2000.

[11] Budowski G. Agroforestry in the tropics: a programme of work. Catie: Turrialba 1977.

[12] Price N, Ed. Short course: Agroforestry for the humid tropics. Catie: Turrialba 1982.

[13] Brownrigg L. Home gardening in international development: what the literature shows. Washington, DC: League for International Food Education 1985.

[14] Caballero J. Maya homegardens: past, present and future Etnoecologica 1992; 1: 35-51.

[15] Gladis T, Hammer K, Roose K, Knüpffer H, Azurdia C, Leiva JM. The contribution of tropical home gardens to in situ conservation of plant genetic resources. Examples from Guatemala and Vietnam. In: Hammer K, Gladis T, Eds. Nutzung genetischer ressourcen ökokogischer wert biodiversität. Schriften zu Genetischen Ressourcen. Bonn: ZADI/IGR, 2001; pp 35-48.

[16] Fernandes ECM, O'Kting'ati A, Maghembe JA. The Chagga home gardens: a multistoried agroforestry cropping system on Mt. Kilimanjaro (Northern Tanzania). Agroforestry Syst 1984; 2: 7386.

[17] Okafor JC, Fernándes ECM. Compound farms of southeastern Nigeria: a predominant agroforestry home garden syst with crops and small livestock. Agroforestry Syst 1987; 5: 153-68.

[18] Okigbo B. Home gardens in tropical Africa. In: Landauer K, Brazil M, Eds. Tropical home gardens. Tokyo: UNU Press, 1990; pp 2140.

[19] Asare EO, Oppong SK, Twun-Ampofo. Home gardens in the humid tropics of Ghana. In: Landauer K, Brazil M, Eds. Tropical home gardens. Tokyo: UNU Press, 1990; pp 80-93.

[20] Dounias E, Hladik CM. Agroforêts mvae et yasa du Cameroun littoral : fonctions et structures. In: Hladik CM, Hladik A, Pagezy $\mathrm{H}$, et al., Eds. L'alimentation en forêt tropicale : interactions bioculturelles et applications au développement. Paris: Unesco, 1996; pp 1103-26.

[21] Tchatat M. Les jardins de case agroforestiers des basses terres humides du Cameroun: étude de cas des zones forestières des provinces du Centre et du Sud. Doctoral Dissertation. Paris: Université Paris 6: 1996.

[22] Soemarwoto O, Soemarwato I, Karyono, Soekartadiredja EM, Ramlan A. The Javanese home garden as an integrated agroecosystem. Food Nutr Bull 1985; 7: 44-7.

[23] Esquivel M., Hammer K. The Cuban home garden 'conuco': a perspective environment for evolution and in situ conservation of plant genetic resources. Genet Resour Crop Evol 1992; 39: 9-22.

[24] Jensen M. Soil conditions, vegetation structure and biomass of a Javanese homegarden. Agroforestry Syst 1993; 24: 171-86.

[25] Hanstad T, Brown J, Prosterman R. Larger homestead plots as land reform? International experience and analysis from Karnataka. Econ Polit 2002; 37: 3053-62.

[26] Fernandes ECM, Nair PKR. An evaluation of the structure and functions of tropical home gardens. Agric Syst 1986; 21: 279-310.

[27] Chandrashekara UM. Studies on growth and architecture of tree species of home garden agroforestry systems of Kerala. Kerala: KFRI Research Report 1996.

[28] Gajaseni J, Gajaseni N. Ecological rationalities of the traditional homegarden system in the Chao Phraya Basin, Thailand. Agroforestry Syst 1999; 46: 3-23.

[29] Stoler A. Garden use and household economy in rural Java. Bull Indones Econ Stud 1978; 14: 85-101.

[30] Danoesastro H. The role of the home garden as a source of additional family income. Seminar on the Ecology of Home gardens. Bandung: Institute of Ecology 1980. 
[31] Méndez VE, Lok R, Somarriba E. Interdisciplinary analysis of home gardens in Nicaragua: Micro-zonation, plant use and socioeconomic importance. Agroforestry Syst 2001; 51: 85-96.

[32] Dinh Trong Hiêu. Place et symbolique des végétaux dans les jardins domestiques au Vietnam. Cahiers d'Études Vietnamiennes 2003; 16: 1-41.

[33] Guiral C. Diversité des jardins et stratégies paysannes le long d'un gradient altitudinal en Éthiopie centrale. Doctoral dissertation. Paris: MNHN 2009

[34] Hahn E. Die Entsehung der Pflugkultur. Heidelberg: C. Winter 1909.

[35] Ames O. Economic annuals and human culture. Cambridge: Botanical Museum of Harvard University 1939.

[36] van der Veen M. Gardens and fields: the intensity and scale of food production. World Archaeol 2005; 37: 157-163.

[37] Vogl-Lukasser B, Vogl CR. Ethnobotanical research in homegardens of small farmers in the Alpine Region of Osttirol (Austria): Photo essay. Ethnobot Res Appl 2005; 3: 79-98.

[38] Olmos Romera R, Cabrera Bonnet P, Eds. Paraíso cerrado, jardín abierto. El reino vegetal en el imaginario religioso del Mediterráneo. Madrid Ediciones Polifemo: 2005.

[39] Heckler S, Ed. Cultivating community, identity and transition: socio-cultural aspects of homegardens and gardens. Berghahn Books: Oxford; in press.

[40] Eyzaguirre PB, Linares OF, Eds. Home gardens and agrobiodiversity. Smithsonian Books: Washington 2004.

[41] Brun T, Reynaud J, Chevassus-Agnes S. Food and nutritional impact of one home garden project in Senegal. Ecol Food Nutr 1989; 23: 91-108.

[42] Immink MDC. Measuring food production and consumption, and the nutritional effects of tropical home gardens. In: Landauer K, Brazil M, Eds. Tropical home gardens. Tokyo: UNU Press, 1990; pp. 126-37.

[43] Marek T, Brun T, Reynaud J. Do home garden projects improve income and nutritional status? A case study in Senegal. Food Nutr Bull 1990; 12: 20-25.

[44] Dharmasena KH, Wijeratne M. Analysis of nutritional contribution of home gardening. Tropenlandwirt 1996; 97: 149-158.

[45] Marsh R. Building on Traditional gardening to improve household food security. Roma: FAO 1998.

[46] Helen Keller International/Asia-Pacific. Homestead food production - A strategy to combat malnutrition and poverty. Jakarta: Helen Keller International 2001.

[47] Makhotla L, Hendriks S. Do home gardens improve the nutrition of rural pre-schooler in Lesotho? Dev Southern Afr 2004; 21: 575-81.

[48] Westmacott R. African-American gardens and yards in the rural south. Knoxville: University of Tennessee Press 1992.

[49] Finerman R, Sackett R. Using home gardens to decipher health and healing in the Andes. Med Anthropol Q 2003; 17: 459-82.

[50] Heckler SL. Herbalism, home gardens, and hybridization. Wõthïhã medicine and cultural change. Med Anthropol Q 2007; 21: 41-63.

[51] Dounias E. Black and white. The ecological, social, and symbolic opposition between frontyard and backyard in Fang homegardens in Southern Cameroon. In: Heckler S, Ed. Cultivating community, identity and transition: socio-cultural aspects of homegardens and gardens. Oxford: Berghahn Books; in press.

[52] Dounias E. Le câble pris au piège du conservateur, technologie du piégeage et production cynégétique chez les Mvae du sud Cameroun forestier. In: Bahuchet S, Bley D, Pagezy H, et al., Eds.
L'Homme et la forêt tropicale. Éditions de Bergier: Châteauneuf de Grasse: 2000; pp. 281-300.

[53] Dounias E. Agriculture des Mvae du sud Cameroun littoral forestier: étude dynamique des composantes de l'agroécosystème et des plantes cultivées alimentaires. In: Froment A, de Garine I, Binam Bikoï C, Eds. Anthropologie alimentaire et développement en Afrique intertropicale: du biologique au social. Paris: ORSTOM-l'Harmattan, 1996; pp. 155-72.

[54] Dounias E, Bahuchet S. Habitat semi-permanent en forêt d'Afrique centrale. In Brun B, Dufour AH, Picon B, Ribéreau-Gayon MD, Eds. Cabanes, cabanons et campements. Formes sociales et rapports à la nature en habitat temporaire. Châteauneuf de Grasse: Éditions de Bergier, 2002; pp. 161-81.

[55] Cureau A. Les sociétés primitives de l'Afrique équatoriale. Paris: Colin 1912.

[56] Compiègne V (Marquis de), Marche A. Voyage dans le HautOgooué de la Pointe Fétiche à la Rivière Ivindo. Bull Soc Géogr 1874; 6: 225-39.

[57] Dounias E, Froment A. When forest-based hunter-gatherers become sedentary. Unasylva 2007; 57: 26-33.

[58] Nakatani N. Antioxidative and antimicrobial constituents of herbs and spices. In: Charalambous G, Ed. Spices, Herbs, and Edible fungi. Amsterdam: Elsevier, 1994; pp 251-72.

[59] Dounias E, McKey D, Selzner A. Some don't like it hot: Evolutionary implications of the limited use of spices by tropical forest hunter-gatherers. Ethnobot Res Appl; in press.

[60] Okah M. Les Bëti du Sud-Cameroun et le rituel So. Doctoral Dissertation. Paris: École Pratique des Hautes Études 1965.

[61] Devienne P, Bobard P, Pinhas C. Le ver de cayor, agent d'une myiase furonculeuse. Insectes 2004; 135: 23-4.

[62] Von Hagen GT. Lehrbuch der Bulu Sprache. Berlin: Radetzki 1914.

[63] Fernández JW. Christian acculturation and Fang witchcraft. Cahiers d'Études Afr 1961; 6: 244-70.

[64] Alexandre P. Protohistoire du groupe beti-bulu-fang. Essai de synthèse provisoire. Cahiers d'Études Africaines 1965; 5: 503-60.

[65] Mallart-Guimera L. Médecine et pharmacopée evuzok. Paris: Université de Nanterre 1977.

[66] Mallart-Guimera L. Ni dos, ni ventre. Paris: Université de Nanterre 1981.

[67] Laburthe-Tolra P. Initiations et sociétés secrètes au Cameroun. Essai sur la religion beti. Paris: Khartala 1985.

[68] Binet J, Ed. Sociétés de danse chez les Fang du Gabon. ORSTOM: Paris 1972.

[69] Barbier JC, Ed. Femmes du Cameroun. Mères pacifiques, femmes rebelles. ORSTOM-Karthala: Paris 1985.

[70] Dounias E, Colfer CJP. Socio-cultural dimensions of diet and health in forest dwellers systems: Examples from Central Africa and Indonesia. In: Colfer CJP, Ed. Human health and forests. A global overview of issues, practice and policy. London: Earthscan Books, 2008; pp. 279-96.

[71] Soemarwoto O. Home gardens: A traditional agroforestry system with a promising future. In: Steppler $H$, Nair PKR, Eds. Agroforestry: A decade of development. Nairobi: ICRAF, 1987; 157-70.

[72] Nair PKR. Do tropical home gardens elude science, or is it the other way around? Agroforestry Syst 2001; 53: 239-45.

[73] Watson JW, Eyzaguirre PB, Eds. Home gardens and in situ conservation of plant genetic resources in farming systems. IPGRI: Roma 2001.

This is an open access article licensed under the terms of the Creative Commons Attribution Non-Commercial License (http://creativecommons.org/licenses/by$\mathrm{nc} / 3.0 /$ ), which permits unrestricted, non-commercial use, distribution and reproduction in any medium, provided the work is properly cited. 